\title{
Performance of a breeding program for irrigated rice in Southeast Brazil
}

\author{
A.C. Silva Júnior ${ }^{1}$, V.Q. Carneiro ${ }^{1}$, I.G. Santos $^{1}$, W.G Costa ${ }^{1}$, \\ R.D.S. Rosado ${ }^{1}$, C.D. Cruz ${ }^{1}$ and P.C. Soares ${ }^{2}$ \\ ${ }^{1}$ Departamento de Biologia Geral, Universidade Federal de Viçosa, Viçosa, \\ MG, Brasil \\ ${ }^{2}$ Empresa de Pesquisa Agropecuária de Minas Gerais, Campus da \\ Universidade Federal de Viçosa, Viçosa, MG, Brasil \\ Corresponding author: A.C. Silva Júnior \\ E-mail: antonio.silva.c.junior@gmail.com \\ Genet. Mol. Res. 18 (3): gmr18332 \\ Received April 26, 2019 \\ Accepted July 04, 2019 \\ Published July 19, 2019 \\ DOI http://dx.doi.org/10.4238/gmr18332
}

\begin{abstract}
Estimating the performance of a rice breeding program is possible by means of indexes such as the replacement rate, which quantifies the dynamism of the breeding program and provides the rate of included, excluded, maintained and renewed genotypes year after year. We evaluated the performance of the irrigated rice breeding program in the state of Minas Gerais, conducted by the EPAMIG/UFV/EMBRAPA consortium. A total of 210 lines were evaluated in the municipalities of Janaúba, Leopoldina and Lambari from 1993 to 2016. The average number of genotypes included, maintained and excluded in each year were calculated, along with the replacement rate percentage. The average genotype replacement rate was $44 \%$ for Lambari and Janaúba, and $43 \%$ for Leopoldina. The average maintenance in Lambari was 39\%, and in Janaúba and Leopoldina it was $40 \%$. In all localities, the mean rate of inclusion of genotypes was higher than the average exclusion rate, indicating good efficiency in the irrigated rice breeding program. However, new strategies should be used in the irrigated rice breeding program to increase the genetic basis of lines and increase the replacement rate.
\end{abstract}

Key words: Oryza sativa; Biometry; Genetic Progress; Breeding Program 


\section{INTRODUCTION}

The breeding program for flooded rice in Minas Gerais is carried out by the Empresa de Pesquisa Agropecuária de Minas Gerais (EPAMIG) in partnership with the Embrapa - National Center for Research on Rice and Beans (CNPAF) and the Federal University of Lavras (UFLA) (Santos et al., 1999). As a result of this partnership, 31 rice cultivars were made available in Minas Gerais, of which 18 are suitable for irrigated crops in floodplains and 13 for rainfed conditions.

The strategy for this success is to obtain, gradually, genetic gains while preserving the genetic variability for continuous improvement of yield, grain quality, resistance to diseases and other agronomic traits (Breseghello et al., 2011; Colombari Filho et al., 2013; Martínez et al., 2014; Morais Júnior et al., 2017; Barros et al., 2018). Another important impact of the program is the high rate of adoption of new rice cultivars by farmers, which in itself demonstrates the efficiency of the breeding program (Soares et al., 1999). However, it is of utmost importance to monitor the breeding program efficiency over time, providing quantitative indicators to correct directions and point out new strategies (Breseghello et al., 2011).

One way of quantifying the efficiency of a breeding program is by assessing the genotypic replacement rate, which expresses the dynamics of the breeding program by providing the percentage of genotype taxa included, excluded, maintained and renewed from year to year (Cruz, 2014). The dynamics established by the inclusion, exclusion and renewal of cultivars is the most efficient way to evaluate the performance of the breeding program (Federizzi et al., 2012; Ceccarelli, 2015).

We can summarize the dynamics of a breeding program through an indicator that expresses genetic progress. This information, in addition to verifying the success of the breeding program, quantifies the impact of favorable allele transfer strategies during selection process, guides future research and re-evaluates the methods used to obtain new varieties (Soares et al., 2005; Menezes Júnior et al., 2008; Streck et al., 2018). Finally, global gain estimates are useful as indicators of the effectiveness of the choice and conduct of the methodology used, as well as the potential of the exploited germplasm (Breseghello et al., 2011).

In evaluating the performance of the breeding program it should be considered that it involves large investments, financial, physical and human, in the long term, and that the decisions taken periodically will have consequences years later in the performance of the resulting cultivars. However, achievements can help predict trends and plan future breeding program adjustments.

There are few studies related to the genotypic substitution rate in cereals; these include wheat (Carginin et al., 2008; Follmann et al., 2017) and rice (Atroch et al., 2000; Reis et al., 2015) studies. To further this line of research, we examined the performance of the irrigated rice breeding program in the state of Minas Gerais, administered by the EPAMIG/UFV/EMBRAPA consortium.

\section{MATERIAL AND METHODS}




\section{Description of the field experiments}

The experiments were carried out in the state of Minas Gerais, Brazil, in the experimental fields of the Empresa de Pesquisa Agropecuária de Minas Gerais (EPAMIG) in the municipalities of Leopoldina (latitude 21 $31^{\prime} 48.01^{\prime \prime} \mathrm{S}$, longitude $42^{\circ} 38^{\prime} 24.00^{\prime \prime} \mathrm{W}$ ), Lambari (latitude 21 ${ }^{\circ} 58^{\prime} 11.24^{\prime \prime} \mathrm{S}$, longitude 4520'59.60" W) and Janaúba (latitude $15^{\circ} 48^{\prime} 0.77^{\prime \prime} \mathrm{S}$, longitude $\left.43^{\circ} 17^{\prime} 59.09^{\prime \prime} \mathrm{W}\right)$. A total of 210 lines were evaluated for grain yield between 1993 and 2016. In each experiment, 25 lines were evaluated, with the exception of the years 1994, 1995 and 1999, during which 12, 24 and 26 lines were evaluated, respectively (Table 1).

Table 1. Experimental information, including number of replications, spacing, total area and useful area of the plots of Value and Cultivation and Use (VCU's) trials of rice cultivars conducted from 1993/94 to 2015/16 in Minas Gerais, Brazil.

\begin{tabular}{lllll}
\hline $\begin{array}{l}\text { Years } \\
\text { Agricultural }\end{array}$ & Repetitions & $\begin{array}{l}\text { Size of the } \\
\text { Plots }(\mathbf{m})\end{array}$ & $\begin{array}{l}\text { Total area of } \\
\text { Plots }\left(\mathbf{m}^{2}\right)\end{array}$ & Useful Area of Plots $\left(\mathbf{m}^{2}\right)$ \\
\hline $1993 / 94$ & 4 & $5 \times 1.50$ & 7.5 & 3.6 \\
$1994 / 95$ & 4 & $5 \times 1.50$ & 7.5 & 3.6 \\
$1995 / 96$ & 4 & $5 \times 1.50$ & 7.5 & 3.6 \\
$1996 / 97$ & 4 & $5 \times 1.50$ & 7.5 & 3.6 \\
$1997 / 98$ & 4 & $5 \times 1.50$ & 7.5 & 3.6 \\
$1998 / 99$ & 4 & $5 \times 1.50$ & 7.5 & 3.6 \\
$1999 / 00$ & 4 & $5 \times 1.50$ & 7.5 & 4.8 \\
$2001 / 02$ & 4 & $5 \times 1.80$ & 9.0 & 4.8 \\
$2002 / 03$ & 3 & $5 \times 1.80$ & 9.0 & 4.8 \\
$2003 / 04$ & 3 & $5 \times 1.80$ & 9.0 & 4.8 \\
$2004 / 05$ & 3 & $5 \times 1.80$ & 9.0 & 3.6 \\
$2005 / 06$ & 3 & $5 \times 1.80$ & 9.0 & 3.6 \\
$2006 / 07$ & 3 & $5 \times 1.50$ & 9.0 & 3.6 \\
$2007 / 08$ & 3 & $5 \times 1.50$ & 7.5 & 3.6 \\
$2008 / 09$ & 3 & $5 \times 1.50$ & 7.5 & 3.6 \\
$2009 / 10$ & 3 & $5 \times 1.50$ & 7.5 & 3.6 \\
$2010 / 11$ & 3 & $5 \times 1.50$ & 7.5 & 3.6 \\
$2012 / 13$ & 3 & $5 \times 1.50$ & 7.5 & 3.6 \\
$2013 / 14$ & 3 & $5 \times 1.50$ & 7.5 & 7.5 \\
$2014 / 15$ & 3 & $5 \times 1.50$ & 7.5 & \\
$2015 / 16$ & 3 & $5 \times 1.50$ & & \\
\hline
\end{tabular}

All experiments were carried out in randomized blocks, with four replications each until 2002. From that year on, the same design was adopted using three replications. The experimental plots from 1993 to 1999 and from 2000 to 2016 consisted of five meter rows. The plots were composed of five rows with $0.30 \mathrm{~m}$ spacing between rows. The harvest area was composed of the three internal rows to exclude any border effects. From 2001 to 2007, the plots were composed of six rows, and the four central meters of the five internal rows were considered. The irrigation rate was gradually increased as the plants developed. The experiments were conducted in agreement with the technical recommendations for the crop (Embrapa,1997).

Emphasis was given to the grain yield in $\mathrm{kg} \cdot \mathrm{ha}^{-1}$, since this is the main trait evaluated in breeding programs. For the analysis of genotype performance, the GENES software (Cruz, 2016) was used. 


\section{Number and average of genotypes included, maintained and excluded each} year

From a set of information related to the performance of a genotype group evaluated in a given period of time, the following information is obtained:

I: number of new genotypes in relation to the previous year. For year 1 we have I equal to zero. For the next years, I is determined as follows:

$$
I_{i}=n_{i j}-n_{i, j-1}
$$

where: $\mathrm{n}_{\mathrm{ij}}$ : number of genotypes evaluated in year $\mathrm{i} ; \mathrm{n}_{\mathrm{ij}}=\mathrm{n}_{\mathrm{j}, \mathrm{i}}$ : $\mathrm{i}$ : number of genotypes evaluated in year $\mathrm{i}$ and $\mathrm{j}$.

$\mathrm{M}$ : number of genotypes kept for evaluation in the following year:

$$
\mathrm{M}_{\mathrm{i}}=\mathrm{n}_{\mathrm{i}, \mathrm{j}+1}
$$

For the last year $(\mathrm{i}=\mathrm{a})$ we have: $\mathrm{M}_{\mathrm{a}}=\mathrm{n}_{\mathrm{aa}}$.

E: number of genotypes excluded from the evaluation in the following year:

$$
\mathrm{E}_{\mathrm{i}}=\mathrm{n}_{\mathrm{ii}}-\mathrm{n}_{\mathrm{i}, \mathrm{i}+1}
$$

For the last year $(i=a)$ we have: $E_{a}=0$.

$\mathrm{T}$ : number of genotypes evaluated in the year in which $\mathrm{Ti}=\mathrm{n}_{\mathrm{ii}}$; $\mathrm{MI}$ : mean of new (renewed) genotypes in relation to the previous year. For the first year, $\mathrm{MI}_{\mathrm{a}}=0$; $\mathrm{MM}$ : mean of the genotypes kept for evaluation in the subsequent year; ME: mean of the genotypes excluded from the evaluation in the subsequent year. For the last year, $\mathrm{ME}_{\mathrm{a}}=0$; and MT: mean of all genotypes evaluated in the year.

\section{Genotypic replacement rate}

The genotypic replacement rate quantifies the breeding program dynamism and provides the rate of genotypes included, excluded, maintained and renewed from year to year. The rate estimates are:

$$
\begin{aligned}
& \% \mathrm{M}=\frac{100 M}{M+E+I} \\
& \% \mathrm{E}=\frac{100 E}{M+E+I} \\
& \% \mathrm{I}=\frac{100 I}{M+E+I}
\end{aligned}
$$

It was considered that $\mathrm{M}$ was the number of genotypes maintained from year to year. For years 1 and $2, M=n_{12}$; $E$ is the number of genotypes excluded in the previous year. For years 1 and $2, E=n_{11}-n_{21}$; $I$ is the number of genotypes included in the subsequent year. For years 1 and $2, I=n_{22}-n_{21}$.

The rate of new genotypes created by the breeding program compared to the previous year $(\% \mathrm{I})$ is also a measure of a breeding program's dynamism. The rate of renewal $(\% \mathrm{R})$, expressed by the rate of new genotypes among those being tested in a given year, is given by: 


$$
\mathrm{R}=\frac{100 I}{M+I}
$$

\section{RESULTS AND DISCUSSION}

The level of cultivars' adoption by farmers is certainly the most efficient qualitative way of evaluating the performance of a plant breeding program. However, even in programs of proven success, quantitative indicators are needed. It allows, for example, evaluation of the genotypic replacement rate using experimental data, such as those available from VCU's assays. In this context, using the results of evaluation of grain yield of the network of VCU's trials, it was possible to evaluate the dynamism of the flood-irrigated rice breeding program developed in Minas Gerais from 1993/1994 to 2015/2016 (Table 2).

Table 2: Genotype replacement rate $(\%)$ in Value for Cultivation and Use testing of irrigated rice in each pair of years, from 1993 to 2016 in Minas Gerais, Brazil.

\begin{tabular}{|c|c|c|c|c|c|c|c|c|c|c|c|c|}
\hline \multirow{2}{*}{ Year } & \multicolumn{4}{|c|}{ Lambari } & \multicolumn{4}{|c|}{ Janaúba } & \multicolumn{4}{|c|}{ Leopoldina } \\
\hline & I & $\mathbf{E}$ & M & $\mathbf{R}$ & I & $\mathbf{E}$ & M & $\mathbf{R}$ & I & $\mathbf{E}$ & M & $\mathbf{R}$ \\
\hline 1994 & 0.65 & 0.29 & 0.06 & 0.92 & 0.65 & 0.29 & 0.06 & 0.92 & 0.65 & 0.29 & 0.06 & 0.92 \\
\hline 1995 & 0.31 & 0.31 & 0.37 & 0.46 & 0.31 & 0.31 & 0.37 & 0.46 & 0.31 & 0.31 & 0.37 & 0.46 \\
\hline 1996 & 0.48 & 0.46 & 0.07 & 0.88 & 0.48 & 0.46 & 0.07 & 0.88 & 0.48 & 0.46 & 0.07 & 0.88 \\
\hline 1997 & 0.49 & 0.49 & 0.02 & 0.96 & 0.49 & 0.49 & 0.02 & 0.96 & 0.49 & 0.49 & 0.02 & 0.96 \\
\hline 1998 & 0.44 & 0.44 & 0.11 & 0.8 & 0.31 & 0.28 & 0.42 & 0.42 & 0.31 & 0.28 & 0.42 & 0.42 \\
\hline 1999 & 0.42 & 0.42 & 0.16 & 0.72 & 0.41 & 0.43 & 0.16 & 0.72 & 0.41 & 0.43 & 0.16 & 0.72 \\
\hline 2001 & 0.19 & 0.19 & 0.61 & 0.24 & 0.42 & 0.42 & 0.16 & 0.72 & 0.42 & 0.42 & 0.16 & 0.72 \\
\hline 2002 & 0.34 & 0.34 & 0.32 & 0.52 & 0.19 & 0.19 & 0.61 & 0.24 & 0.19 & 0.19 & 0.61 & 0.24 \\
\hline 2003 & 0.22 & 0.22 & 0.56 & 0.28 & 0.38 & 0.38 & 0.25 & 0.6 & 0.34 & 0.34 & 0.32 & 0.52 \\
\hline 2004 & 0.34 & 0.34 & 0.32 & 0.52 & - & - & - & - & 0.22 & 0.22 & 0.56 & 0.28 \\
\hline 2005 & 0.11 & 0.11 & 0.79 & 0.12 & 0.34 & 0.34 & 0.32 & 0.52 & 0.34 & 0.34 & 0.32 & 0.52 \\
\hline 2006 & 0.31 & 0.31 & 0.39 & 0.44 & 0.11 & 0.11 & 0.79 & 0.12 & 0.11 & 0.11 & 0.79 & 0.12 \\
\hline 2007 & 0.14 & 0.14 & 0.72 & 0.16 & 0.31 & 0.31 & 0.39 & 0.44 & 0.31 & 0.31 & 0.39 & 0.44 \\
\hline 2008 & 0.29 & 0.29 & 0.43 & 0.4 & 0.14 & 0.14 & 0.72 & 0.16 & 0.14 & 0.14 & 0.72 & 0.16 \\
\hline 2009 & 0.07 & 0.07 & 0.85 & 0.08 & 0.29 & 0.29 & 0.43 & 0.4 & 0.29 & 0.29 & 0.43 & 0.4 \\
\hline 2010 & 0.34 & 0.34 & 0.32 & 0.52 & 0.07 & 0.07 & 0.85 & 0.08 & 0.07 & 0.07 & 0.85 & 0.08 \\
\hline 2011 & 0.22 & 0.22 & 0.56 & 0.28 & 0.34 & 0.34 & 0.32 & 0.52 & 0.34 & 0.34 & 0.32 & 0.52 \\
\hline 2013 & 0.19 & 0.19 & 0.61 & 0.24 & 0.22 & 0.22 & 0.56 & 0.28 & 0.22 & 0.22 & 0.56 & 0.28 \\
\hline 2014 & 0.22 & 0.22 & 0.56 & 0.28 & 0.19 & 0.19 & 0.61 & 0.24 & 0.19 & 0.19 & 0.61 & 0.24 \\
\hline 2015 & - & - & - & & 0.22 & 0.22 & 0.56 & 0.28 & 0.22 & 0.22 & 0.56 & 0.28 \\
\hline Average & 0.31 & 0.29 & 0.39 & 0.44 & 0.31 & 0.29 & 0.4 & 0.44 & 0.31 & 0.29 & 0.4 & 0.43 \\
\hline
\end{tabular}

I: number of new genotypes in relation to the previous year; M: number of genotypes maintained for evaluation in the subsequent year; E: number of genotypes excluded from the evaluation in the subsequent year; T: number of genotypes evaluated in the year.

The process of indicating varieties for commercial plantations is continuous and dynamic. Thus it is recommended to periodically include new cultivars in substitution to those less productive and with less commercial acceptance. Table 2 provides indicators to quantify the dynamism of the irrigated rice breeding program in the State of Minas Gerais. The average grain yield of the genotypes evaluated in the periods from 1993 to 2016 was $3631 \mathrm{~kg} \cdot \mathrm{ha}^{-1}$ in Lambari. At this location, the highest average of all evaluated genotypes was recorded in the agricultural year 2002/2003, which corresponds to $6812 \mathrm{~kg} . \mathrm{ha}^{-1}$ and the lowest $2465 \mathrm{~kg} \cdot \mathrm{ha}^{-1}$ in the 2010/2011 agricultural year (Table 3). In Janaúba and Leopoldina, the average results of the genotypes were better than Lambari, since in Janaúba 
and Leopoldina the overall mean reached $6282 \mathrm{~kg} \mathrm{ha}^{-1}$ and $5790 \mathrm{~kg} \cdot \mathrm{ha}^{-1}$, respectively (Table $3)$.

Table 3. Estimation of the average yield $\left(\mathrm{kg}_{\mathrm{ha}} \mathrm{h}^{-1}\right)$ of the new strains, maintained, excluded and evaluated each year in the program for the improvement of irrigated rice, from 1993 to 2016, in Lambari - MG, Janaúba - MG and Leopoldina - MG.

\begin{tabular}{|c|c|c|c|c|c|c|c|c|c|c|c|c|}
\hline \multirow{2}{*}{ YEAR } & \multicolumn{4}{|c|}{ Lambari } & \multicolumn{4}{|c|}{ Janaúba } & \multicolumn{4}{|c|}{ Leopoldina } \\
\hline & MI & MM & ME & MT & MI & MM & ME & MT & MI & MM & ME & MT \\
\hline 1994 & - & 2158 & 1863 & 1912 & - & 1009 & 9973 & 9993 & - & 7186 & 6909 & 6955 \\
\hline 1995 & 4584 & 4516 & 4307 & 4420 & 8003 & 8412 & 7673 & 8073 & 7459 & 7827 & 7126 & 7506 \\
\hline 1996 & 4842 & 5295 & 5027 & 5060 & 7427 & 7491 & 7624 & 7607 & 5680 & 5443 & 5656 & 5629 \\
\hline 1997 & 3449 & 4069 & 3372 & 3400 & 6666 & 6336 & 6687 & 6673 & 5643 & 5668 & 5662 & 5662 \\
\hline 1998 & 4492 & 4937 & 4381 & 4492 & 6253 & 6446 & 6037 & 6282 & 5318 & 5687 & 4768 & 5320 \\
\hline 1999 & - & - & - & 3059 & 6391 & 6550 & 6389 & 6432 & 5689 & 5683 & 5880 & 5827 \\
\hline 2001 & 3026 & 3136 & 3030 & 2903 & 6387 & 6391 & 6387 & 6388 & 5270 & 5609 & 5270 & 5365 \\
\hline 2002 & 2766 & 3039 & 2471 & 6812 & 8313 & 8308 & 8191 & 8280 & 5282 & 5378 & 5585 & 5427 \\
\hline 2003 & 7213 & 6655 & 6957 & 1282 & 6182 & 5937 & 6326 & 6170 & 6060 & 5538 & 5146 & 5334 \\
\hline 2004 & 1429 & 1238 & 1397 & 2745 & 5191 & 5213 & - & 5213 & 5601 & 6112 & 4964 & 5790 \\
\hline 2005 & 2879 & 3172 & 2351 & 2309 & - & 4115 & 3979 & 4044 & 6141 & 6532 & 5757 & 6129 \\
\hline 2006 & 1940 & 2468 & 1148 & 4575 & 6978 & 6747 & 6268 & 6689 & 7007 & 7138 & 6265 & 7033 \\
\hline 2007 & 5057 & 5096 & 3912 & 2189 & 5773 & 5675 & 5156 & 5447 & 8435 & 8185 & 7574 & 7916 \\
\hline 2008 & 2277 & 2349 & 1345 & 4269 & 8282 & 8409 & 7812 & 8314 & 6057 & 6612 & 5294 & 6401 \\
\hline 2009 & 4820 & 4239 & 4313 & 4892 & 3894 & 3443 & 3681 & 3538 & 4076 & 4039 & 4036 & 4038 \\
\hline 2010 & 4885 & 4878 & 5046 & 2465 & 5465 & 5446 & 4904 & 5403 & 5814 & 5944 & 5701 & 5924 \\
\hline 2011 & 8733 & 9625 & 8653 & 5468 & 6135 & 6466 & 6483 & 6475 & 4391 & 5071 & 4803 & 4932 \\
\hline 2013 & 5280 & 5455 & 5500 & 3862 & 4248 & 4171 & 4251 & 4194 & 3903 & 4093 & 3700 & 3983 \\
\hline 2014 & 3997 & 3966 & 3532 & 4600 & 5601 & 5427 & 5438 & 5430 & 2708 & 2647 & 2753 & 2673 \\
\hline 2015 & 5043 & 4773 & 4157 & 2808 & 5352 & 5695 & 5303 & 5585 & 7744 & 7646 & 7654 & 7648 \\
\hline 2016 & 2989 & 2808 & - & - & 6008 & 5990 & - & 5990 & 7085 & 6854 & - & 6854 \\
\hline
\end{tabular}

MI: mean of new (renewed) genotypes in relation to the previous year; MM: mean of the genotypes maintained for evaluation in the subsequent year; ME: mean of the genotypes excluded from the evaluation in the subsequent year; MT: mean of the total genotypes evaluated in the year.

The highest total genotypes average corresponded to $8314 \mathrm{~kg} \cdot \mathrm{ha}^{-1}$ in the crop year 2007/2008, in the municipality of Janaúba. In this same place, the lowest mean was 3538 kg.ha ${ }^{-1}$ in the 2008/2009 crop year. In Leopoldina, the highest average was $7916 \mathrm{~kg}^{-h^{-1}}$ agricultural year of 2006/2007 and the lowest average of $2673 \mathrm{~kg}^{-h^{-1}}$ agricultural year 2013/2014 (Table 3). In spite of the low total averages, Lambari was the site that obtained the highest average of the new genotypes in relation to the previous year $\left(8733 \mathrm{~kg} \cdot \mathrm{ha}^{-1}\right)$, and also the highest average of the genotypes excluded from the evaluation in the following year $\left(8653 \mathrm{~kg} \cdot \mathrm{ha}^{-1}\right.$ ) (Table 3).

From the point of view of rigor in the breeding of irrigated rice in Minas Gerais, the agricultural years 1993/1994 to 1999/2000, obtained a greater number of new genotypes in relation to the previous year and the smaller number of genotypes kept for evaluation in the year (Table 2), and, consequently, higher was required for the breeder's requirement in this period for the evaluation of genotypes. It was verified that the Irrigated Rice Improvement Program in the State of Minas Gerais promoted a good genotype renewal rate throughout the evaluated period (Table 2), demonstrating the program's dynamism in launching cultivars, providing new crop options for the farmer. Similar results were found in works such as Carginin et al. (2008), in wheat, who obtained 33\% renewal rate and in Soares et al., (1999), Atroch and Nunes (2000), in rice, who found rates of renewal of $44 \%$ and $46 \%$ 
respectively, these authors reported that the values found evidence high vitality of breeding programs.

In general, the genotype maintenance rate in this study was considered medium (Table 2). Branquinho et al. (2016) obtained a result of 25\%, which was considered low. Soares et al. (1999) and Dovale et al. (2012) obtained good results (56\% and 58\%, respectively). Atroch and Nunes (2000) verified an average maintenance rate of $38 \%$ in the period from 1997/1998 to 2011/2012 and Reis et al. (2015) obtained a mean maintenance rate of $63 \%$ in rice. In other crops, such as cotton (Moresco, 2003) and wheat (Carginin et al., 2007), average maintenance rates of $44 \%$ and $55 \%$, respectively, were found to be optimal.

The effectiveness of a breeding program is also related to the inclusion and exclusion rate. When the inclusion rate is higher in relation to the exclusion rate, it indicates that the breeding program is contributing to the release of varieties, allowing new cultivation options for the farmer (Cruz, 2003). In all places, the mean inclusion rate was higher than the average exclusion rate, indicating good efficiency of the irrigated rice breeding program in Minas Gerais (Table 2).

The mean maintenance rates were $39 \%$ in Lambari and $40 \%$ in Janaúba and Leopoldina (Table 2). The lowest maintenance rate in Lambari compared to other locations is due to the analysis being made with different farm years, since 20 years of agricultural production were evaluated in Lambari, while in the other locations 21 agricultural years were evaluated. This makes it possible to obtain an estimate of the variation of the environment between the years under evaluation. In this sense, the environmental effect is due to the contrast between the genotypes common to the years considered (Atroch and Nunes, 2000). The greater the number of common treatments every couple of years, the more accurate is the environmental effect estimate. Thus, the data analysis leads to greater safety in the estimation of genetic progress by the consequent reduction caused by the experimental errors and the interactions of genotypes with years.

This difference between sites is due to the representative effect of a complex set of factors acting at random. This involves climatic factors, incidence of pests and diseases as well as factors peculiar to certain moments in time and space. Thus, it is not expected, contrary to the directed action of the improvement, a favorable temporal action of the environment over the years. Another explanation is that the best genotype in one location may not be the best in another, that is, differentiated behavior of genotypes versus environmental variations, because of this difference between environment, which expresses the interaction genotypes by environments (Colombari Filho et al., 2013 and Kleinknecht et al., 2016). However, in addition to the productivity that the genotype-environment interaction is visible, it is worth noting that the attributes related to irrigated rice grain quality are highly related not only to genetic but also environmental factors (Cameron et al., 2008; Hakata et al., 2012; Lyman et al., 2013; Li et al., 2014; Xu et al., 2015; Streck et al., 2017; Streck et al., 2018). The physical attributes of the grains are very complex quantitative traits because they are controlled by maternal and cytoplasmic effects (Streck et al., 2018). Therefore, many genetic mechanisms and interactions with the environment are still obscure (Shi et al., 2002; Zhou et al., 2009).

It is important to note that, in all places, the averages were higher than the average in the State of Minas Gerais during the period from 1993 to 2016. Therefore, the breeding program of irrigated rice in Minas Gerais provides a great contribution of cultivars to the 
rice farmer. In this sense, the first cultivar recommended for the State was IR 841 in 1975 and in the agricultural year 1976/1977 the production in the State with this cultivar was 897 $\mathrm{kg} \cdot \mathrm{ha}^{-1}$. The first variety of rice launched by the rice improvement program in Minas Gerais was in fact the IAC 899 variety in 1978 and in the first agricultural year after its launch the productivity obtained in the State was approximately $1300 \mathrm{~kg} \cdot \mathrm{ha}^{-1}$ showing the efficiency of the rice improvement program in the State (CONAB, 2016).

Reis et al., (2015) evaluated 108 genotypes of flooded rice in the period 1997/1998 to 2011/2012 in the VCU's tests of the Empresa de Pesquisa Agropecuária de Minas Gerais (EPAMIG) of the irrigated rice breeding program. According to these authors there was balance in the irrigated rice improvement of the EPAMIG program regarding the inclusion and exclusion of materials in this study.

An important caveat that must take into account the high maintenance rates that limit genetic gains to rice productivity, mainly due to the low exploitation of the genetic base for the crop available in germplasm banks, and also because this characteristic is quantitative (Streck et al., 2018). This restricts the potential for genotypic variability of elite materials to be explored. An ideal situation would be that replacement rates were equal to or even higher than that observed in the period 1998 to 2012, which was 26\% (Reis et al., 2015). In view of these results, new strategies should be used in the breeding program of irrigated rice in Minas Gerais to increase the genetic base of the lines, as well as increase in the rate of replacement and reduction in the rate of maintenance and selection in a specific environment.

In view of these results, the gain to productivity has not been satisfactory at the present time, and the elite lineages have not exceeded the cultivars already launched. This can be justified by the importance that the program has given to the selection of other traits than grain yield (Santos et al., 1999), for example, the one focused on releasing cultivars with high productivity potential, good quality and healthy grains, resistance to biotic and abiotic factors and good adaptation to growing conditions (Streck et al., 2018). Corroborating the previous discourse, it is necessary to point out the need to establish new breeding strategies aiming at obtaining cultivars superior to those already launched, since it is known that irrigated rice still has sufficient productive potential and variability to be exploited (Santos et al., 1999).

According to Soares et al. (2008), the indication technology of rice cultivars for commercial plantations is dynamic and periodically new cultivars are recommended as substitutes for those less productive or with less commercial acceptance. In view of this, the development of new cultivars is crucial to help increase food availability and the success of breeding programs that depends on the existence of genetic variability and also, breeders recommended the formation of a population base based on the interbreeding of higher cultivars and genetically divergent (Santos et al., 2017; Rabelo et al., 2015). This is of paramount importance for the success of breeding programs (Cruz, Ferreira, \& Pessoni, 2011).

\section{CONCLUSIONS}

The breeding program of irrigated rice developed in Minas Gerais in the agricultural years 1993/1994 to 2015/2016 obtained a significant increase in grain yield. Although the 
results are satisfactory, new strategies should be used to increase the genetic base of the lines, as well as the rate of replacement.

\section{ACKNOWLEDGMENTS}

The authors thank the FAPEMIG, CNPq and CAPES for financial support and researchers at the Embrapa Rice and Beans Dr. Orlando Peixoto de Morais (in memory) and Paula Pereira Torga. This study was financed in part by the Coordenação de Aperfeiçoamento de Pessoal de Nível Superior - Brasil (CAPES) - Finance Code 001.

\section{CONFLICTS OF INTEREST}

The authors declare no conflict of interest.

\section{REFERENCES}

Atroch AL and Nunes GHS (2000). Progresso genético em arroz de várzea úmida no Estado do Amapá. Pesq. Agropec. Bras. 35: 767-771. http://dx.doi.org/10.1590/S0100-204X2000000400013.

Barros MS, Morais Júnior OP, Melo PGS, et al. (2018). Effectiveness of early-generation testing applied to upland rice breeding. Euphytica. 214: 61. doi:10.1007/s10681-018-2145-z.

Branquinho RG (2016). Regionalização de áreas produtoras de arroz de terras altas e dimensionamento de sua rede experimental para avaliação genotípica. 117 pp. Doctoral Thesis in Plant Genetics, Escola de Agronomia e Engenharia de Alimentos, Universidade Federal de Goiás.

Breseghello F, Morais OP, Pinheiro PV, et al. (2011). Results of 25 years of upland rice breeding in Brazil. Crop Sci. 51: 914-923. doi:10.2135/cropsci2010.06.0325.

Cameron DK, Wang YJ and Moldenhauer KA (2008). Comparison of physical and chemical properties of medium-grain rice cultivars grown in California and Arkansas. J. Food Sci. 73: 72-78. DOI: 10.1111/j.1750-3841.2007.00631.x.

Cargnin A, Souza MA and Fronza V (2008). Progress in breeding of irrigated wheat for the Cerrado region of Brazil. Crop Breed. Appl. Biotechnol. 8: 39-46.

Ceccarelli S (2015). Efficiency of Plant Breeding. Crop Sci. 55: 87-97. doi:10.2135/cropsci2014.02.0158.

Colombari Filho JM, Resende MDV, Morais OP, et al. (2013). Upland rice breeding in Brazil: a genotypic evaluation simultaneous for stability, adaptability and grain yield. Euphytica. 192: 117-129. doi:10.1007/s10681-013-0922-2.

Conab, Companhia Nacional de Abastecimento. Available at: http://www.conab.gov.br. Accessed 01, January 2019.

Cruz CD (2016). Genes Software - extended and integrated with the R, Matlab and Selegen. Acta Sci. Agron. 38: 547552. doi:10.4025/actasciagron.v38i4.32629.

Cruz CD and Carneiro PCS (2014). Modelos biométricos aplicados ao melhoramento genético. Vol 2. $3^{\text {rd }}$ ed. Editora UFV, Viçosa.

Cruz CD, Ferreira MF and Pessoni LA (2011). Biometria aplicada ao estudo da diversidade genética. 1st ed. Editora Suprema, Visconde do Rio Branco, MG.

DoVale JC, Soares PC, Cornélio VMO, Reis MS, et al. (2012). Contribuição genética na produtividade do arroz irrigado em Minas Gerais no período de 1998 a 2010. Bragantia. 71(4): 460-466.

Empresa Brasileira de Pesquisa Agropecuária (1977). Manual de métodos de pesquisa em arroz, $1^{\text {a }}$ aproximação. 106. EMBRAPA/CNPAF, Goiânia-GO.

Federizzi LC, Carbonell SAM, Pacheco MT and Nava IC (2012). Breeders' work after cultivar development: the stage of recommendation. Crop Breed. Appl. Biotechnol. 12: 67-74. doi: 10.1590/S1984-70332012000500008.

Follmann DN, Cargnelutti Filho A, Lúcio AD, et al. (2017). Genetic progress in homogeneous regions of wheat cultivation in Rio Grande do Sul State, Brazil. Genet. Mol. Res. 16: gmr16019517. DOI: 10.4238/gmr16019517.

Hakata M, Kuroda M, Miyashita T, Yamaguchi T, et al. (2012). Suppression of $\alpha$-amylase genes improves quality of rice grain ripened under high temperature. Plant Biotechnol. Jour. 10: 1110-1117. doi: 10.1111/j.14677652.2012.00741.x.

Kleinknecht K, Möhring J, Laidig F, Meyer U, et al. (2016). A simulation-based approach for evaluating the efficiency of multi-environment trial designs. Crop Sci. 56: 2237-2250. doi:10.2135/cropsci2015.07.0405.

Li JY, Wang J and Zeigler RS (2014). The 3,000 rice genomes project: new opportunities and challenges for future rice research. GigaScience. 3: 8. doi: 0.1186/2047-217X-3-8.

Lyman NB, Jagadish KS, Nalley LL, Dixon BL, et al. (2013). Neglecting rice milling yield and quality underestimates economic losses from high-temperature stress. Plos One. 8: e72157. doi: 10.1371/journal.pone.0072157. 
Martínez CP, Torres EA and Chatel M (2014). Rice Breeding in Latin America. In: Janick J. Plant Breeding Reviews. 38: 187-277. doi:10.1002/9781118916865.ch05.

Menezes Júnior JAN, Ramalho MAP and Abreu AFB (2008). Seleção recorrente para três caracteres do feijoeiro. Bragantia. 67: 833-838.

Morais Júnior OP, Breseghello F, Duarte JB, Morais OP, et al. (2017). Effectiveness of Recurrent Selection in Irrigated Rice Breeding. Crop Sci. 57: 3043-3058. doi:10.2135/cropsci2017.05.0276.

Moresco ER (2003). Progresso genético no melhoramento do algodoeiro no Estado de Mato Grosso. 79 pp. Doctoral Thesis in Plant Genetics, Escola Superior de Agricultura Luís de Queiroz, Piracicaba.

Rabelo HO, Guimaraes JFR, Pinheiro JB and Silva EF (2015). Genetic base of Brazilian irrigated rice cultivars. Crop Breed. Appl. Biotechnol. 15: 146-153. doi.org/10.1590/1984-70332015v15n3a26.

Reis GG, Fritsche-Neto R, Soares PC, Cornélio VMO, et al. (2015). Accuracy and genetic progress of agronomic traits in irrigated rice program in Brazil. Afr. J. Agric. Res. 10: 4032-4038 doi: 10.5897/AJAR2014.9112.

Santos IG, Carnairo VQ, Silva Junior AC, Cruz CD, et al. (2019). Self-organizing maps in the study of genetic diversity among irrigated rice genotypes. Acta Sci. Agron. 41: e39803. doi:10.4025/actasciagron.v41i1.39803.

Santos PG, Soares PC, Soares AA, Morais OP, et al. (1999). Avaliação do progresso genético obtido em 22 anos no melhoramento do arroz irrigado em Minas Gerais. Pesq. Agropec. Bras. 34: 1889-1896. doi:10.1590/S0100204X1999001000016.

Shi CH, Wu JG, Lou XB, Zhu J, et al. (2012). Genetic analysis of transparency and chalkiness area at different filling stages of rice (Oryza sativa L.). Field Crops Res. 76: 1-9. doi: 10.1016/S0378-4290(02)00011-4.

Soares PC, Melo PGS, Melo LC and Soares AA (2005). Genetic gain in an improvement program of irrigated rice in Minas Gerais. Crop Breed. Appl. Biotechnol. 5: 142-148.

Soares AA, Santos PG, Morais OP, Soares PC, et al. (1999). Progresso genético obtido pelo melhoramento do arroz de sequeiro em 21 anos de pesquisa em Minas Gerais. Pesq. Agropec. Bras. 34: 415-424. doi.org/10.1590/S0100204X1999000300013.

Streck EA, Aguiar GA, Magalhães Júnior AM, Facchinello PHK, et al. (2017). Variabilidade fenotípica de genótipos de arroz irrigado via análise multivariada. Rev. Ciên. Agron. 48: 101-109 doi: 10.5935/1806-6690.20170011.

Streck EA, Magalhaes AM, Aguiar GA, Facchinello PKH, et al. (2018). Genetic Progress in 45 Years of Irrigated Rice Breeding in Southern Brazil. Crop Sci. 58: 1094-1105. doi: 10.2135/cropsci2017.06.0383.

$\mathrm{Xu} \mathrm{Q}$, Chen W and Xu Z (2015). Relationship between grain yield and quality in rice germplasms grown across different growing areas. Breed. Sci. 65: 226-232. doi: 10.1270/jsbbs.65.226.

Zhou LJ, Jiang L, Zhai HQ and Wan JM (2009). Current status and strategies for improvement of rice grain chalkiness. Hereditas 31: 563-572. doi: 10.3724/SP.J.1005.2009.00563. 